\title{
Metal concentrations in intertidal water and surface sediment along the west coast of the Cape Peninsula, Cape Town, South Africa
}

\author{
C Sparks ${ }^{1 *}$, J Odendaal ${ }^{2}$ and $R$ Snyman ${ }^{1}$ \\ 'Department of Conservation and Marine Sciences, Cape Peninsula University of Technology, PO Box 652, Cape Town, 8000, South Africa \\ ${ }^{2}$ Department of Environmental and Occupational Studies, Cape Peninsula University of Technology, PO Box 652, Cape Town, South Africa
}

\begin{abstract}
The concentrations of metals in intertidal water and surface sediment were measured at Scarborough, Hout Bay, Green Point, Milnerton and Bloubergstrand in Cape Town, South Africa, between Autumn 2010 and Autumn 2011. In terms of Pollution Load Index (PLI) of metals in the sediment, the sites were ranked in the following order: Bloubergstrand > Hout Bay $>$ Green Point $>$ Milnerton $>$ Scarborough. Seasonally, metal loads were highest in Autumn 2011 and lowest in Autumn 2010. The higher metal concentrations reported in sediment suggested that both localised anthropogenic and natural weathering were the sources of metals recorded. Surprisingly, metal concentrations were similar to those reported in 1985 for the same sites, suggesting that the intertidal environment in Cape Town has not been increasingly contaminated with metals. The findings provide a baseline of metal concentrations that can be used for further research in the region.
\end{abstract}

Keywords: metals, intertidal water, sediment, contamination factor, pollution load index, Cape Town

\section{INTRODUCTION}

The effects of contaminants on organisms are often not evident until changes in the ecosystem have taken place. One way of determining whether compounds are likely to be having deleterious effects is to measure concentrations in the environment, which can serve as an early warning of potential contaminant threats. This can be accomplished by having a monitoring system that measures the level and types of chemical compounds prevalent in a system. Metals are elements that occur naturally in the environment and are considered ideal targets for monitoring pollution in sentinel organisms (Clark et al., 1992). Sources of metal contamination are anthropogenic, due to agricultural activity, industrial efforts and an increase in urbanisation. Metals such as $\mathrm{Cd}, \mathrm{Cu}, \mathrm{Ni}, \mathrm{Pb}$ and $\mathrm{Zn}$ tend to accumulate in aquatic environments due to their chemical characteristics (Clark et al., 1992; Ankley et al., 1996), in particular in surface sediment (Sarki et al., 1995)

Surface sediment can be considered to be a heterogeneous combination of particles of dissimilar compounds (such as detritus, inorganic particles, organic matter, plankton bacteria, etc.). These compounds in turn comprise inorganic and organic components (Martin et al., 1987). According to El-Sammak and Aboul-Kassim (1999), analysing surface sediments can indicate the prevailing quality of a system and the pollution history of a particular area. The indication of quality obtained, however, is not a permanent one, as metals are not necessarily fixed by the surface sediment but may be recycled via both biological and chemical mechanisms. According to Salomons and Förstner (1984), fixation and recycling can happen within the surface sediments as well as between surface sediment and the water column.

Certain metals in surface sediments are vital for the ecological functioning of aquatic biota (e.g. $\mathrm{Mn}$ and $\mathrm{Cu}$ ) (Ünlü et al., 2008). The majority of metals (such as $\mathrm{Cu}, \mathrm{Sn}, \mathrm{Al}$ and $\mathrm{Cd}$ ) enter the marine environment via natural pathways such as erosion

\footnotetext{
* To whom all correspondence should be addressed.

? +2721 460-3766; e-mail: sparksc@cput.ac.za

Received 18 June 2015; accepted in revised form 16 November 2016
}

(Clark et al., 1992). Deleterious amounts of anthropogenic metals in the surface sediment can bioaccumulate within the organisms, which in turn can negatively impact functioning of the ecosystem. Generally, concentrations of metals in the surface sediment are used as indicators of the health of that ecosystem (Ünlü et al., 2008). Prevalence of metals in surface sediments is considered a better indicator than water given the continual flux of the aqueous part of the ecosystem (Sarki et al., 1995).

Marine pollution has detrimental effects on marine ecosystems and is increasingly becoming of great concern to most countries. Metals accumulate over time and can pose threats to the condition of the water column and health of benthic marine organisms. It is therefore important to monitor both the surface sediment and aqueous environment, as these form sinks for pollutants. Because of their chemical characteristics, elevated concentrations of metals in the water column can accumulate in the surface sediment which in turn can result in toxic environments for organisms inhabiting benthic areas (Salomons and Förstner, 1984).

There is limited published data about metal concentrations in coastal water and surface sediment in Cape Town. A review of metal concentrations in southern African coastal waters by Hennig (1985) indicated that the region's coastal waters and sediment, when compared to other regions at the time, did not have higher concentrations of metals (in both water and sediment), and it was suggested that the southern African coastline was not polluted. The objective of this study was to investigate the concentrations of metals in the intertidal water and surface sediments along the west coast of the Cape Peninsula, Cape Town, to determine metal concentrations in intertidal waters and surface sediments.

\section{MATERIALS AND METHODS}

\section{Study area}

Sampling took place at 5 sites on the west coast of the Cape Peninsula, South Africa: Scarborough ( $\left.34^{\circ} 11^{\prime} S, 18^{\circ} 17^{\prime} \mathrm{E}\right)$, Hout Bay ( $\left.34^{\circ} 02^{\prime} \mathrm{S}, 18^{\circ} 21^{\prime} \mathrm{E}\right)$, Green Point ( $\left.33^{\circ} 54^{\prime} \mathrm{S}, 18^{\circ} 23^{\prime} \mathrm{E}\right)$, Milnerton ( $\left.33^{\circ} 53^{\prime} \mathrm{S}, 18^{\circ} 28^{\prime} \mathrm{E}\right)$ and Bloubergstrand $\left(33^{\circ} 48^{\prime} \mathrm{S}\right.$, 
$\left.18^{\circ} 27^{\prime} \mathrm{E}\right)$ (Fig. 1). The shoreline along the Cape Peninsula is dominated by rocky shores interspersed with pocket beaches of sand or mixed sand and rock. The geomorphology is comprised mainly the Malmesbury rock group with granite underlying most of the western part of the Peninsula (Glass, 1981).

The area falls within a Mediterranean-type climatic region, typified by winter rainfall from successional cold fronts from the west and dry south-easterly winds during the summer. The annual mean temperature in the region is $17^{\circ} \mathrm{C}\left(\right.$ range $\left.\pm 10^{\circ} \mathrm{C}\right)$ (Shannon, 1985). Because it is in a winter rainfall region, the area receives the bulk of its annual precipitation $(500-700 \mathrm{~mm})$ from April to August (Shannon, 1985).

Scarborough was the southern-most sampling site, situated in a coastal conservation village. The town is approximately $10 \mathrm{~km}$ north of the Cape Point Nature Reserve. Hout Bay is a $\mathrm{U}$-shaped bay approximately $2.5 \mathrm{~km}$ long and $2 \mathrm{~km}$ wide (Fricke et al., 1979). A commercial fishing harbour, boat maintenance and fish processing facilities are situated on the western side of the bay. The Green Point site is situated at the northern most end of the Sea Point promenade and is a popular recreational area in Cape Town. The Milnerton site is situated close to an outfall pipe and within a couple of kilometres of the port of Cape Town. Bloubergstrand is an urbanised area with a rocky shoreline situated approximately $20 \mathrm{~km}$ north of Cape Town.

\section{Fieldwork}

Temperature and $\mathrm{pH}$ were measured in the shallow surf zone at each sampling site using a Hanna Hi 9810 portable pH/EC/ TDS meter. Samples were collected seasonally during Autumn 2010, Winter 2010, Spring 2010, Summer 2010 and Autumn 2011 at spring low tide, with sampling always commencing at the southern-most site (Scarborough). Water and surface sediment samples ( $n=7$ at each site) were collected for metal analysis and were frozen at $-20^{\circ} \mathrm{C}$ until analysis.

\section{Metal analysis}

Metal analysis was done according to the method of Odendaal and Reinecke (1999). Frozen sediment samples were defrosted and oven-dried for $48 \mathrm{~h}$ at $60^{\circ} \mathrm{C}$. Ground sediment aliquots $( \pm$ $0.2 \mathrm{~g}$ ) and defrosted water samples $(5 \mathrm{~mL})$ were digested using $10 \mathrm{~mL}$ of nitric acid $\left(\mathrm{HNO}_{3}\right)$. Samples were then heated to $40^{\circ} \mathrm{C}$ in a Grant UBD heating block for $1 \mathrm{~h}$, and thereafter to $120^{\circ} \mathrm{C}$ for $3 \mathrm{~h}$. The digestates were allowed to cool, filtered through Whatman No. 6 filter paper, and then through $0.45 \mu \mathrm{m}$ membrane micro-filter (Millipore) using a syringe. Thereafter, $5 \mathrm{~mL}$ digestates were placed in plastic centrifuge tubes; $10 \mathrm{~mL}$ distilled water was added and the tubes stored in a refrigerator until further analysis.

A blank accompanied all samples during analysis. The concentrations of $\mathrm{Mn}, \mathrm{Fe}, \mathrm{Cu}, \mathrm{Zn}, \mathrm{Cd}$ and $\mathrm{Pb}$ were analysed in 7 replicates at the Central Analytical Facilities laboratory at the University of Stellenbosch. General principles of US EPA method $6020 \mathrm{~A}$ were used in setting up quality control protocols during analysis and reporting of data. An Agilent 7700x ICP-MS with Octopole Reaction System was used for metal analysis. All metal concentrations were within $2 \%$ relative standard deviation (RSD) of the certified concentrations. Concentrations of metals are presented as $\mu \mathrm{g} \cdot \mathrm{g}^{-1}$ dry weight for sediments and as $\mathrm{mg} \cdot \mathrm{L}^{-1}$ for water.

\section{Statistical analysis}

All calculations and data analysis were done using STATISTICA software (V10; Statsoft, Inc). Results are presented as means

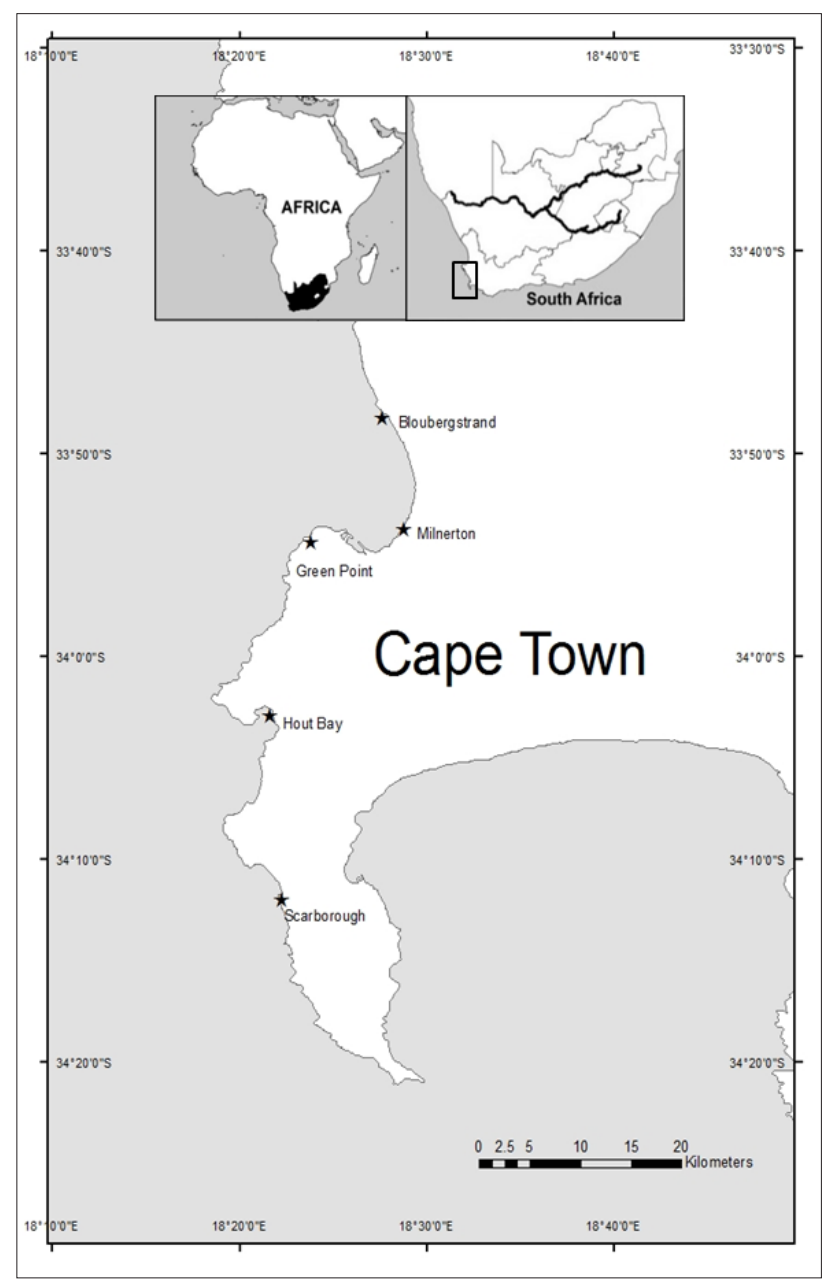

Figure 1

Map showing the position of the sampling sites in the Cape Peninsula, Cape Town

and standard deviations $( \pm \mathrm{SD})$. One-way ANOVA was used to determine significant seasonal and spatial differences in mean metal concentrations in sediment and water samples. The data were tested for normality and homogeneity of variance using Kolmogorov-Smirnoff and Levene's tests, respectively, prior to post-hoc comparisons. Data that did not meet the requirements were $\log _{10}$ transformed. Post-hoc comparisons were made using the Tukey Honest Significant Difference (HSD) test to identify statistically significant data $(p<0.05)$. Spearman Rank correlations were used to determine relationships between metal concentrations in water and sediment at both spatial and temporal levels.

To quantify the magnitude of contamination by metals in sediment, the Contamination Factor (CF) was determined. The $\mathrm{CF}$ indicates the factor by which background concentrations are exceeded at a site and is calculated as follows (El-Sammak and Aboul-Kassim, 1999):

\section{$C F=\frac{\text { Metal concentration of sediment }}{\text { Background concetration of sediment }}$}

The Pollution Load Index (PLI) was used to determine the contamination loads of metals at the sites using the equation of El-Sammak and Aboul-Kassim (1999): 


$$
P L I=\sqrt[6]{\left(C F_{F e}\right)\left(C F_{M n}\right)\left(C F_{C u}\right)\left(C F_{Z n}\right)\left(C F_{C d}\right)\left(C F_{P b}\right)}
$$

According to El-Sammak and Aboul-Kassim (1999), a PLI $>1.2$ suggests that metal contamination loads are high and PLI $<1.2$ that they are not high.

\section{RESULTS}

Intertidal water temperatures ranged between 14.4 and $18.6^{\circ} \mathrm{C}$. The mean temperature for the study period was $15.7\left( \pm 1.3^{\circ} \mathrm{C}\right)$. The lowest mean temperatures were recorded during Winter $2010\left(15.2^{\circ} \mathrm{C}\right)$, followed by Spring $2010\left(15.3^{\circ} \mathrm{C}\right)$. The highest temperatures $\left(16.4^{\circ} \mathrm{C}\right)$ were in Autumn 2010 and Autumn 2011. Within seasons, there were no significant differences in temperature between sites $(p>0.05)$. The $\mathrm{pH}$ ranged between 7.4 and 8.1 , with a mean of 7.7. For most sites, the $\mathrm{pH}$ increased from Autumn 2010 to Winter 2010 and then decreased during Summer 2010 (except for Hout Bay). Within seasons, there were no significant differences in $\mathrm{pH}$ between the sites $(p>0.05)$.

\section{Metals in intertidal water}

The mean Fe concentration in intertidal water was $3.28 \mathrm{mg} \cdot \mathrm{L}^{-1}$ (Table 1). Fe concentrations were lowest $\left(<0.3 \mathrm{mg} \cdot \mathrm{L}^{-1}\right)$ at Scarborough, Hout Bay and Green Point, with the highest concentrations recorded during Winter 2010 at Milnerton (4.17 mg. $\left.\mathrm{L}^{-1}\right)$ and Bloubergstrand $\left(69.53 \mathrm{mg} \cdot \mathrm{L}^{-1}\right)$. Mean concentrations for other metals were generally very low or below detection limits (see Table 1).

\section{Metals in sediment}

The mean Fe concentration in sediment was $835.68 \pm$ $1249.36 \mu \mathrm{g} \cdot \mathrm{g}^{-1}$ (Table 2), with the highest concentrations recorded at Green Point during Summer 2010. Seasonally, mean Fe concentrations were lowest during Autumn 2010 at Scarborough and highest in Summer 2010 at Green Point. Significant differences in sediment Fe concentrations were recorded between Scarborough and Milnerton $(p<0.05)$ as well as between Autumn 2010, Spring 2010 and Summer 2010. Mean sediment Mn concentration was $9.25( \pm 9.19) \mu \mathrm{g} \cdot \mathrm{g}^{-1}$, with the highest concentrations recorded at Green Point during Summer 2010. There were no significant differences in sediment Mn concentration between sites, but there were significant differences seasonally. Mean $\mathrm{Cu}$ concentration in sediment for all sites was $2.57( \pm 2.89) \mu \mathrm{g} \cdot \mathrm{g}^{-1}$, with the highest concentrations at Hout Bay in Spring 2010 and no significant differences between seasons. Highest $\mathrm{Zn}$ concentration was recorded at Bloubergstrand during Winter 2010, with a mean concentration of 14.30 $( \pm 50.55) \mu \mathrm{g} \cdot \mathrm{g}^{-1}$. Only Bloubergstrand had significantly higher $\mathrm{Zn}$ concentrations $(p<0.05)$. Values for Cd were the lowest of all the metals $\left(0.31 \pm 1.19 \mu \mathrm{g} \cdot \mathrm{g}^{-1}\right)$. The mean $\mathrm{Pb}$ concentration in sediment was $1.89 \pm\left(1.88 \mu \mathrm{g} \cdot \mathrm{g}^{-1}\right)$, with the highest concentrations recorded at Green Point during Summer 2010. There were no significant differences in $\mathrm{Pb}$ concentrations between sites but significant differences were observed between seasons.

\section{Correlations between water and sediment concentrations}

There were no statistically significant correlations between sediment and water samples when all of the metal data were combined (Table 3 ). However, there was a strong positive correlation $(r>0.9)$ between sediment and water Cd concentrations during Autumn 2010. Weak positive correlations were recorded for $\mathrm{Zn}$ and $\mathrm{Pb}$ during Summer 2010 as well as for $\mathrm{Zn}$ and $\mathrm{Cd}$ during Autumn 2011. There was a very weak significant positive correlation $(r<0.6)$ between water and sediment concentrations for $\mathrm{Pb}$ at $\mathrm{Scarborough}, \mathrm{Fe}, \mathrm{Mn}$ and $\mathrm{Pb}$ at Hout Bay, $\mathrm{Fe}$ and $\mathrm{Cd}$ at Green Point, as well as $\mathrm{Fe}, \mathrm{Cu}$ and $\mathrm{Cd}$ at Bloubergstrand $(p<0.05)$. There were no significant correlations between water and sediment metal concentrations at Milnerton, and Bloubergstrand had significant weak negative correlations between sediment and water Fe concentrations.

\section{Contamination factors and pollution load indices}

The CF was calculated for each metal and categorised per season and site. The calculations were based on background concentrations previously reported by Hennig (1985) or using unpublished data from the Department of Environmental Affairs for each site (Table 4). Per season, CF was lowest in Autumn 2011 (1.75) and highest during Winter 2010 (19.78) (Table 5). During Autumn 2010, Scarborough had the lowest CF for all metals combined. The order of mean seasonal CFs from high est to lowest was: Winter $2010>$ Summer $2010>$ Spring 2010 $>$ Autumn 2010 > Autumn 2011. On a spatial scale, the CFs ordered from highest to lowest were: Bloubergstrand (34.44) $>$ Hout Bay (6.24) > Green Point (2.34) > Milnerton (1.03) > Scarborough (0.854).

\section{DISCUSSION}

Metals have the ability to induce detrimental effects in marine organisms when present at elevated concentrations (Kennish, 1997), with consequences for ecological functioning. Since the marine environment off Cape Town has ecological and economic value, knowledge about this coastal area is pertinent and could influence environmental management strategies. Metal concentrations in sediment were compared to the sediment quality guidelines for the Benguela Current Large Marine Ecosystem (BCLME) in southern Africa (Taljaard, 2006). The guidelines for the BCLME are as follows: Cd: $0.68 \mu \mathrm{g} \cdot \mathrm{g}^{-1}$, Cu: $18.7 \mu \mathrm{g} \cdot \mathrm{g}^{-1}, \mathrm{~Pb}: 30.2 \mu \mathrm{g} \cdot \mathrm{g}^{-1}$ and $\mathrm{Zn}: 124 \mu \mathrm{g} \cdot \mathrm{g}^{-1}$. None of the metal concentrations at the sites were above the guidelines suggested by Taljaard (2006), apart from $\mathrm{Zn}$ at Bloubergstrand during Winter $2010\left(198.71 \mu \mathrm{g} \cdot \mathrm{g}^{-1}\right)$.

Fe has the potential to occur in high concentrations in the natural environment, stemming from natural sources (Giarratano et al., 2010). According to Rebelo (2011), vegetation in Cape Town is strongly tied to geological composition and has been used to determine vegetation types. Fynbos is rich in Fe (up to $1136 \mu \mathrm{g} \cdot \mathrm{g}^{-1}$ in proteoid fynbos communities) (Mustart and Cowling, 1993) and a natural source is considered the major contributor to the Fe concentrations recorded for this study. Similarly, Giarratano et al. (2010) noted that Fe concentrations from their study must have been from natural origins as there would not have been a human activity that could have caused such levels of metal input to the system.

According to Hennig (1985), in 1979 Fe concentrations in coastal waters along the west coast of the Cape Peninsula were $15 \mathrm{mg} \cdot \mathrm{L}^{-1}$ at Green Point and Milnerton during winter, with lower concentrations during spring $\left(<4.5 \mathrm{mg} \cdot \mathrm{L}^{-1}\right)$. Quick and Roberts (1992) reported Fe concentrations of $22.8 \mathrm{mg} \cdot \mathrm{L}^{-1}$ in surface water at Milnerton and $6.78 \mathrm{mg} \cdot \mathrm{L}^{-1}$ at Green Point. In the present study, the Fe concentration in surface waters 
was low (mean $\left.=3.28 \mathrm{mg} \cdot \mathrm{L}^{-1}\right)$, with elevated concentrations recorded at Bloubergstrand during Winter 2010. The elevated Fe concentrations at Bloubergstrand could be as a result of currents carrying Fe from Milnerton towards Bloubergstrand (Quick and Roberts, 1992). In the present study, Fe concentrations in sediment were higher than concentrations recorded by Hennig (1985) for Hout Bay, Green Point and Bloubergstrand. At Green Point, Fe was $23 \%$ higher than that recorded by Hennig (1985) for the same site.

$\mathrm{Mn}$ is an essential micronutrient for plants and animals (Wright and Welbourn, 2002). In aquatic ecosystems, Mn does not occur naturally as a metal but is found in various salts and minerals, frequently in association with Fe compounds (Duffus, 1980; Wright and Welbourn, 2002). Industrial discharges also account for elevated concentrations of $\mathrm{Mn}$ in receiving waters
(Duffus, 1980; Hutzinger, 1980; Wright and Welbourn, 2002). According to Hennig (1985) the maximum surface water Mn concentration in Table Bay was $1.8 \mathrm{mg} \cdot \mathrm{L}^{-1}$. None of the sites sampled in the present study had Mn concentrations greater than $1 \mathrm{mg} \cdot \mathrm{L}^{-1}$. Sediment Mn concentrations recorded in the present study are similar to those reported by Hennig (1985).

$\mathrm{Cu}$ occurs naturally in seawater and its concentrations range between 0.03 and $0.38 \mathrm{mg} \cdot \mathrm{L}^{-1}$ (average of $0.25 \mathrm{mg} \cdot \mathrm{L}^{-1}$ ), with concentrations as high as $2 \mathrm{mg} \cdot \mathrm{L}^{-1}$ occurring in the marine environment (Riley and Chester, 1983). According to Hennig (1985) the average $\mathrm{Cu}$ concentration in South African coastal waters in 1979 was $0.899 \mathrm{mg} \cdot \mathrm{L}^{-1}$, which was higher than the average recorded in the present study $\left(0.01 \mathrm{mg} \cdot \mathrm{L}^{-1}\right)$. According to Riley and Skirrow (1975) seawater can retain a maximum of $50 \mathrm{mg} \cdot \mathrm{L}^{-1}$ of $\mathrm{Cu}$ and the concentrations are influenced by

\begin{tabular}{|c|c|c|c|c|c|c|c|}
\hline \multicolumn{8}{|c|}{$\begin{array}{c}\text { TABLE } 1 \\
\text { Metal concentrations in intertidal waters }\left(\mathrm{mg} \cdot \mathrm{L}^{-1}\right)( \pm \mathrm{SD}, \mathrm{n}=7) \text { from the west coast of the Cape Peninsula between } \\
\text { Autumn } 2010 \text { and Autumn } 2011\end{array}$} \\
\hline Site & Season & $\mathrm{Fe}$ & Mn & $\mathrm{Cu}$ & Zn & Cd & $\mathbf{P b}$ \\
\hline \multirow{6}{*}{ Scarborough } & Autumn 2010 & $0.26 \pm 0.08$ & $0.01 \pm 0.00$ & $0.01 \pm 0.00$ & $<$ d.l & $<\mathrm{d} .1$ & $<\mathrm{d} .1$ \\
\hline & Winter 2010 & $0.24 \pm 0.13$ & $0.01 \pm 0.00$ & $<\mathrm{d} .1$ & $<\mathrm{d} .1$ & $<\mathrm{d} .1$ & $<\mathrm{d} .1$ \\
\hline & Spring 2010 & $0.01 \pm 0.03$ & $0.01 \pm 0.00$ & $<$ d.1 & $0.02 \pm 0.06$ & $<\mathrm{d} .1$ & $<\mathrm{d} .1$ \\
\hline & Summer 2010 & $0.23 \pm 0.12$ & $0.01 \pm 0.00$ & $<$ d.1 & $<$ d.l & $<$ d.l & $<$ d.l \\
\hline & Autumn2011 & $0.31 \pm 0.06$ & $0.01 \pm 0.00$ & $0.01 \pm 0.00$ & $<\mathrm{d} .1$ & $<\mathrm{d} .1$ & $<\mathrm{d} .1$ \\
\hline & Site mean & $0.21 \pm 0.14$ & $0.01 \pm 0.01$ & $<\mathrm{d} .1$ & $<\mathrm{d} .1$ & $<\mathrm{d} .1$ & $<\mathrm{d} .1$ \\
\hline \multirow{6}{*}{ Hout Bay } & Autumn 2010 & $0.22 \pm 0.08$ & $0.01 \pm 0.00$ & $<$ d.l & $0.03 \pm 0.06$ & $<$ d.l & $<$ d.l \\
\hline & Winter 2010 & $0.25 \pm 0.12$ & $0.02 \pm 0.00$ & $0.02 \pm 0.03$ & $<\mathrm{d} .1$ & $<\mathrm{d} .1$ & $<\mathrm{d} .1$ \\
\hline & Spring 2010 & $<\mathrm{d} .1$ & $<\mathrm{d} .1$ & $<\mathrm{d} .1$ & $<\mathrm{d} .1$ & $<\mathrm{d} .1$ & $<\mathrm{d} .1$ \\
\hline & Summer 2010 & $0.40 \pm 0.18$ & $0.01 \pm 0.00$ & $<$ d.1 & $<\mathrm{d} .1$ & $<\mathrm{d} .1$ & $<\mathrm{d} .1$ \\
\hline & Autumn2011 & $0.38 \pm 0.12$ & $0.02 \pm 0.00$ & $0.03 \pm 0.02$ & $0.01 \pm 0.02$ & $<\mathrm{d} .1$ & $<\mathrm{d} .1$ \\
\hline & Site mean & $0.25 \pm 0.19$ & $0.01 \pm 0.01$ & $0.01 \pm 0.02$ & $0.01 \pm 0.02$ & $<\mathrm{d} .1$ & $<\mathrm{d} .1$ \\
\hline \multirow{6}{*}{ Green Point } & Autumn 2010 & $0.01 \pm 0.00$ & $0.01 \pm 0.00$ & $0.01 \pm 0.00$ & $0.01 \pm 0.00$ & $<\mathrm{d} .1$ & $<\mathrm{d} .1$ \\
\hline & Winter 2010 & $0.19 \pm 0.09$ & $0.02 \pm 0.00$ & $0.01 \pm 0.03$ & $<$ d.l & $<\mathrm{d} .1$ & $<\mathrm{d} .1$ \\
\hline & Spring 2010 & $<\mathrm{d} .1$ & $0.01 \pm 0.00$ & $<\mathrm{d} .1$ & $<\mathrm{d} .1$ & $<\mathrm{d} .1$ & $<\mathrm{d} .1$ \\
\hline & Summer 2010 & $0.26 \pm 0.08$ & $0.01 \pm 0.00$ & $<\mathrm{d} .1$ & $0.12 \pm 0.10$ & $<\mathrm{d} .1$ & $<\mathrm{d} .1$ \\
\hline & Autumn2011 & $0.34 \pm 0.07$ & $0.02 \pm 0.00$ & $0.01 \pm 0.00$ & $<\mathrm{d} .1$ & $<\mathrm{d} .1$ & $<\mathrm{d} .1$ \\
\hline & Site mean & $0.17 \pm 0.15$ & $0.01 \pm 0.01$ & $0.01 \pm 0.01$ & $0.03 \pm 0.07$ & $<\mathrm{d} .1$ & $<\mathrm{d} .1$ \\
\hline \multirow{6}{*}{ Milnerton } & Autumn 2010 & $0.38 \pm 0.50$ & $0.02 \pm 0.01$ & $<\mathrm{d} .1$ & $0.03 \pm 0.03$ & $<\mathrm{d} .1$ & $<\mathrm{d} .1$ \\
\hline & Winter 2010 & $4.17 \pm 1.85$ & $0.13 \pm 0.05$ & $<\mathrm{d} .1$ & $2.48 \pm 1.15$ & $0.08 \pm 0.00$ & $0.02 \pm 0.01$ \\
\hline & Spring 2010 & $<\mathrm{d} .1$ & $<$ d.l & $<\mathrm{d} .1$ & $<$ d.1 & $<\mathrm{d} .1$ & $<$ d.l \\
\hline & Summer 2010 & $0.15 \pm 0.29$ & $<\mathrm{d} .1$ & $<\mathrm{d} .1$ & $0.06 \pm 0.09$ & $<\mathrm{d} .1$ & $<\mathrm{d} .1$ \\
\hline & Autumn2011 & $<\mathrm{d} .1$ & $<\mathrm{d} .1$ & $<\mathrm{d} .1$ & $0.01 \pm 0.01$ & $<\mathrm{d} .1$ & $<\mathrm{d} .1$ \\
\hline & Site mean & $0.97 \pm 1.87$ & $0.03 \pm 0.06$ & $<\mathrm{d} .1$ & $0.54 \pm 1.13$ & $0.02 \pm 0.00$ & $<\mathrm{d} .1$ \\
\hline \multirow{6}{*}{ Bloubergstrand } & Autumn 2010 & $0.44 \pm 0.30$ & $0.01 \pm 0.00$ & $0.01 \pm 0.00$ & $0.05 \pm 0.02$ & $<\mathrm{d} .1$ & $<\mathrm{d} .1$ \\
\hline & Winter 2010 & $69.53 \pm 99.35$ & $1.02 \pm 1.25$ & $<$ d.1 & $0.05 \pm 0.05$ & $<\mathrm{d} .1$ & $0.04 \pm 0.02$ \\
\hline & Spring 2010 & $0.02 \pm 0.06$ & $0.01 \pm 0.02$ & $<\mathrm{d} .1$ & $<\mathrm{d} .1$ & $<\mathrm{d} .1$ & $<\mathrm{d} .1$ \\
\hline & Summer 2010 & $0.35 \pm 0.28$ & $0.01 \pm 0.00$ & $<\mathrm{d} .1$ & $0.14 \pm 0.17$ & $<\mathrm{d} .1$ & $<\mathrm{d} .1$ \\
\hline & Autumn2011 & $0.33 \pm 0.11$ & $0.02 \pm 0.00$ & $0.02 \pm 0.01$ & $0.17 \pm 0.29$ & $<\mathrm{d} .1$ & $<\mathrm{d} .1$ \\
\hline & Site mean & $14.48 \pm 51.19$ & $0.22 \pm 0.68$ & $0.01 \pm 0.01$ & $0.08 \pm 0.16$ & $<\mathrm{d} .1$ & $0.01 \pm 0.02$ \\
\hline \multirow{6}{*}{ Season } & Autumn 2010 & $0.27 \pm 0.29$ & $0.01 \pm 0.01$ & $0.01 \pm 0.00$ & $0.02 \pm 0.03$ & $<\mathrm{d} .1$ & $<\mathrm{d} .1$ \\
\hline & Winter 2010 & $14.88 \pm 50.40$ & $0.24 \pm 0.66$ & $0.01 \pm 0.02$ & $0.51 \pm 1.11$ & $0.02 \pm 0.04$ & $0.01 \pm 0.02$ \\
\hline & Spring 2010 & $0.01 \pm 0.03$ & $0.01 \pm 0.01$ & $<$ d.1 & $<\mathrm{d} .1$ & $<\mathrm{d} .1$ & $<\mathrm{d} .1$ \\
\hline & Summer 2010 & $0.28 \pm 0.21$ & $0.01 \pm 0.00$ & $<\mathrm{d} .1$ & $0.07 \pm 0.11$ & $<\mathrm{d} .1$ & $<\mathrm{d} .1$ \\
\hline & Autumn2011 & $0.27 \pm 0.16$ & $0.01 \pm 0.01$ & $0.01 \pm 0.01$ & $0.04 \pm 0.14$ & $<\mathrm{d} .1$ & $<\mathrm{d} .1$ \\
\hline & Season mean & $3.28 \pm 23.61$ & $0.06 \pm 0.31$ & $0.01 \pm 0.01$ & $0.13 \pm 0.55$ & $<\mathrm{d} .1$ & $<\mathrm{d} .1$ \\
\hline
\end{tabular}

$<d . l=$ below detection limit 
riverine sources or shelf surface sediments. The anthropogenic sources of $\mathrm{Cu}$ include metal-plating operations, jewellery and ornamental industries, electrical wiring industries, electronic industries, and antifouling paints (WHO, 1982). From the present study, higher sediment $\mathrm{Cu}$ concentrations were recorded in Spring 2010 and could be indicative of anthropogenic sources of $\mathrm{Cu}$, in particular at Hout Bay and Green Point. Hout Bay is close to a harbour with shipyard maintenance activity which could have contributed to the higher concentrations of $\mathrm{Cu}$ at that site.

According to Riley and Chester (1983), the average concentration of $\mathrm{Zn}$ in marine water is $5 \mathrm{mg} \cdot \mathrm{L}^{-1}$. The average $\mathrm{Zn}$ concentration in South African surface marine waters in 1985 was $6.59 \mathrm{mg} \cdot \mathrm{L}^{-1}$ (Hennig, 1985). The mean $\mathrm{Zn}$ concentration in surface waters recorded during the present study was $0.11 \mathrm{mg} \cdot \mathrm{L}^{-1}$, well below the average reported for South Africa by Hennig (1985). Anthropogenic sources of $\mathrm{Zn}$ include waste from brass and $\mathrm{Zn}$ metal works, waste from yarn, fibre, paint, dye and battery production, steel galvanisation, production of stainless steel tableware, and paper manufacturing (WHO 1982). Some of these industrial activities are prevalent in the Paarden Island industrial area and are therefore possible sources of elevated $\mathrm{Zn}$ concentrations in water at Milnerton. Given that the elevated $\mathrm{Zn}$ concentrations were recorded in winter (rainfall season), surface runoff of $\mathrm{Zn}$ from industrial activities in the surrounding area could have provided a source of $\mathrm{Zn}$ at Bloubergstrand. According to Quick and Roberts (1992), there are two current systems in Table Bay, one in the central bay and the other a bimodal longshore current system. Depending on the wind direction the current circulates in either a clockwise or anti-clockwise direction.

\begin{tabular}{|c|c|c|c|c|c|c|c|}
\hline \multicolumn{8}{|c|}{$\begin{array}{l}\text { TABLE } 2 \\
\text { Concentrations of metals in surface sediment }\left(\mu \mathrm{g} \cdot \mathrm{g}^{-1} \text { dry weight) }( \pm \mathrm{SD}, \mathrm{n}=7) \text { from the west coast of the Cape Peninsula }\right. \\
\text { between Autumn } 2010 \text { and Autumn } 2011 .\end{array}$} \\
\hline Site & Season & Fe & Mn & $\mathrm{Cu}$ & Zn & Cd & $\mathbf{P b}$ \\
\hline \multirow{6}{*}{ Scarborough } & Autumn 2010 & $0.01 \pm 0.00$ & $<$ d.1 & $<$ d.1 & $0.01 \pm 0.00$ & $<\mathrm{d} .1$ & $<$ d.l \\
\hline & Winter 2010 & $26.46 \pm 6.87$ & $1.56 \pm 0.74$ & $<$ d.1 & $<\mathrm{d} .1$ & $0.03 \pm 0.01$ & $0.17 \pm 0.05$ \\
\hline & Spring 2010 & $74.55 \pm 61.32$ & $4.48 \pm 2.37$ & $3.33 \pm 3.81$ & $<$ d.1 & $0.01 \pm 0.01$ & $0.35 \pm 0.16$ \\
\hline & Summer 2010 & $86.56 \pm 40.31$ & $2.34 \pm 1.46$ & $0.14 \pm 0.17$ & $3.79 \pm 4.73$ & $0.01 \pm 0.03$ & $0.32 \pm 0.29$ \\
\hline & Autumn 2011 & $73.63 \pm 30.05$ & $4.89 \pm 5.81$ & $1.01 \pm 0.89$ & $<$ d.1 & $0.06 \pm 0.02$ & $0.61 \pm 0.34$ \\
\hline & Site mean & $54.99 \pm 47.31$ & $2.79 \pm 3.34$ & $0.94 \pm 2.15$ & $0.80 \pm 2.59$ & $0.02 \pm 0.03$ & $0.31 \pm 0.29$ \\
\hline \multirow{6}{*}{ Hout Bay } & Autumn 2010 & $717.24 \pm 72.67$ & $10.18 \pm 0.85$ & $0.71 \pm 0.25$ & $17.22 \pm 23.43$ & $0.10 \pm 0.01$ & $3.78 \pm 0.21$ \\
\hline & Winter 2010 & $733.04 \pm 108.51$ & $9.93 \pm 1.43$ & $<$ d.1 & $<$ d.1 & $0.10 \pm 0.02$ & $1.08 \pm 0.24$ \\
\hline & Spring 2010 & $560.34 \pm 114.81$ & $9.05 \pm 1.07$ & $17.64 \pm 18.95$ & $2.27 \pm 4.90$ & $0.07 \pm 0.01$ & $0.77 \pm 0.21$ \\
\hline & Summer 2010 & $746.19 \pm 198.92$ & $7.30 \pm 1.25$ & $0.22 \pm 0.24$ & $0.40 \pm 0.47$ & $0.01 \pm 0.01$ & $0.62 \pm 0.25$ \\
\hline & Autumn 2011 & $872.52 \pm 121.03$ & $12.23 \pm 1.63$ & $3.22 \pm 2.08$ & $0.37 \pm 0.70$ & $0.15 \pm 0.04$ & $1.31 \pm 0.14$ \\
\hline & Site mean & $726.32 \pm 162.41$ & $9.71 \pm 2.07$ & $4.55 \pm 10.82$ & $3.36 \pm 10.80$ & $0.08 \pm 0.05$ & $1.39 \pm 1.10$ \\
\hline \multirow{6}{*}{ Green Point } & Autumn 2010 & $19.78 \pm 1.88$ & $8.54 \pm 0.99$ & $0.71 \pm 0.13$ & $0.87 \pm 0.23$ & $1.96 \pm 0.22$ & $2.03 \pm 1.27$ \\
\hline & Winter 2010 & $2574.07 \pm 1731.81$ & $21.29 \pm 13.02$ & $<\mathrm{d} .1$ & $2.49 \pm 2.00$ & $0.04 \pm 0.02$ & $4.50 \pm 2.29$ \\
\hline & Spring 2010 & $1495.80 \pm 870.52$ & $16.30 \pm 7.85$ & $5.34 \pm 6.05$ & $25.91 \pm 46.71$ & $0.31 \pm 0.79$ & $4.10 \pm 1.78$ \\
\hline & Summer 2010 & $4345.55 \pm 2403.04$ & $26.61 \pm 13.85$ & $5.78 \pm 7.94$ & $6.52 \pm 3.07$ & $0.01 \pm 0.02$ & $6.00 \pm 3.09$ \\
\hline & Autumn 2011 & $3016.07 \pm 1778.81$ & $24.65 \pm 12.43$ & $4.21 \pm 3.46$ & $12.49 \pm 5.38$ & $0.05 \pm 0.02$ & $4.73 \pm 1.67$ \\
\hline & Site mean & $2409.75 \pm 2098.65$ & $20.05 \pm 12.17$ & $3.34 \pm 5.19$ & $10.12 \pm 22.48$ & $0.40 \pm 0.78$ & $4.39 \pm 2.38$ \\
\hline \multirow{6}{*}{ Milnerton } & Autumn 2010 & $439.14 \pm 121.45$ & $6.51 \pm 1.84$ & $0.36 \pm 0.16$ & $2.31 \pm 2.72$ & $0.06 \pm 0.02$ & $1.75 \pm 0.47$ \\
\hline & Winter 2010 & $539.80 \pm 59.08$ & $5.57 \pm 0.66$ & $1.03 \pm 2.93$ & $11.18 \pm 24.03$ & $0.08 \pm 0.02$ & $2.22 \pm 0.68$ \\
\hline & Spring 2010 & $420.68 \pm 49.70$ & $5.46 \pm 0.79$ & $2.46 \pm 6.96$ & $0.84 \pm 2.39$ & $0.04 \pm 0.01$ & $2.16 \pm 0.32$ \\
\hline & Summer 2010 & $534.58 \pm 27.49$ & $5.51 \pm 0.92$ & $0.39 \pm 0.30$ & $17.08 \pm 12.00$ & $0.04 \pm 0.04$ & $1.83 \pm 0.10$ \\
\hline & Autumn 2011 & $719.68 \pm 232.93$ & $9.33 \pm 3.35$ & $3.38 \pm 4.15$ & $1.86 \pm 5.26$ & $0.17 \pm 0.15$ & $3.00 \pm 1.11$ \\
\hline & Site mean & $535.60 \pm 158.82$ & $6.48 \pm 2.31$ & $1.59 \pm 3.94$ & $6.88 \pm 13.68$ & $0.08 \pm 0.09$ & $2.21 \pm 0.76$ \\
\hline \multirow{6}{*}{ Bloubergstrand } & Autumn 2010 & $760.00 \pm 146.99$ & $11.33 \pm 1.69$ & $1.51 \pm 0.30$ & $6.85 \pm 3.22$ & $0.05 \pm 0.01$ & $1.46 \pm 0.24$ \\
\hline & Winter 2010 & $160.41 \pm 94.84$ & $1.43 \pm 0.56$ & $<$ d.1 & $198.71 \pm 152.80$ & $4.58 \pm 3.58$ & $1.45 \pm 0.85$ \\
\hline & Spring 2010 & $452.00 \pm 287.84$ & $7.54 \pm 3.95$ & $0.24 \pm 0.68$ & $0.08 \pm 0.22$ & $0.02 \pm 0.01$ & $1.08 \pm 0.55$ \\
\hline & Summer 2010 & $642.30 \pm 514.08$ & $11.24 \pm 18.89$ & $0.57 \pm 0.57$ & $28.76 \pm 7.69$ & $<\mathrm{d} .1$ & $1.26 \pm 1.52$ \\
\hline & Autumn 2011 & $330.58 \pm 292.91$ & $5.20 \pm 4.61$ & $1.03 \pm 1.52$ & $7.29 \pm 12.34$ & $0.04 \pm 0.02$ & $0.70 \pm 0.20$ \\
\hline & Site mean & $461.60 \pm 361.70$ & $7.25 \pm 9.35$ & $0.65 \pm 0.94$ & $49.40 \pm 101.70$ & $0.96 \pm 2.41$ & $1.18 \pm 0.84$ \\
\hline \multirow{6}{*}{ Season } & Autumn 2010 & $399.26 \pm 345.32$ & $7.44 \pm 4.24$ & $0.69 \pm 0.56$ & $5.50 \pm 11.62$ & $0.42 \pm 0.77$ & $1.79 \pm 1.34$ \\
\hline & Winter 2010 & $806.76 \pm 1187.31$ & $7.95 \pm 9.30$ & $0.21 \pm 1.31$ & $42.47 \pm 102.81$ & $0.97 \pm 2.38$ & $1.88 \pm 1.83$ \\
\hline & Spring 2010 & $600.67 \pm 622.11$ & $8.57 \pm 5.76$ & $5.80 \pm 11.00$ & $5.82 \pm 22.38$ & $0.09 \pm 0.35$ & $1.69 \pm 1.58$ \\
\hline & Summer 2010 & $1271.04 \pm 1888.67$ & $10.60 \pm 13.17$ & $1.42 \pm 4.04$ & $11.31 \pm 12.34$ & $0.01 \pm 0.03$ & $2.01 \pm 2.56$ \\
\hline & Autumn 2011 & $1002.50 \pm 1310.35$ & $11.26 \pm 9.68$ & $2.57 \pm 2.89$ & $4.40 \pm 7.83$ & $0.09 \pm 0.09$ & $2.07 \pm 1.82$ \\
\hline & Season mean & $835.68 \pm 1249.36$ & $9.25 \pm 9.19$ & $2.21 \pm 5.87$ & $14.30 \pm 50.55$ & $0.31 \pm 1.19$ & $1.89 \pm 1.88$ \\
\hline
\end{tabular}

$<$ d.l = below detection limit 
Current measurements by Quick and Roberts (1992) indicated that the anti-clockwise (northerly) current is driven by southerly winds and subsequently the predominant surface current was in a northerly direction (Van Leperen, 1971). The northward movement of current may result in a northward movement of metals released at Milnerton and could be the cause of elevated metal concentrations (in particular $\mathrm{Zn}$ ) at Bloubergstrand, given the topography and bathymetry (Shannon, 1985) of the area.

Cd occurs in the environment as a result of natural weathering and erosion by rivers; this $\mathrm{Cd}$ is then transported to coastal waters where the average concentration in seawater is $0.1 \mathrm{mg} \cdot \mathrm{L}^{-1}$ or less and between 30 and $1000 \mu \mathrm{g} \cdot \mathrm{g}^{-1}$ in marine surface sediments (WHO, 1992). The average concentration of Cd in South African surface marine waters in 1979 was $0.108 \mathrm{mg} \ell^{-1}$ and $<0.1 \mu \mathrm{g} \cdot \mathrm{g}^{-1}$ dry weight for sediment (Hennig, 1985). According to WHO (1992), anthropogenic sources of Cd include waste from manufacturing protective plating for steel, and stabilisers for PVCs. The relatively high Cd concentrations in sediment at Bloubergstrand could have arisen from surface runoff in the adjacent area as Bloubergstrand has been an area where housing development has increased in recent years.

$\mathrm{Pb}$ is not considered an essential element (Hutzinger, 1980) but does occur in the marine environment due to natural sources from weathering of rocks and forest fires (Riley and Chester, 1983), which may also be a source in Cape Town coastal waters. The results of the present study indicate that $\mathrm{Pb}$ concentrations in surface waters and sediments were generally lower than that recorded by Hennig (1985).

When comparing metal concentrations in surface waters and sediment along the west coast of the Cape Peninsula to those reported by Hennig (1985), it is apparent that metal concentrations have not increased as would have been expected given the rapid rate of industrial development and urbanisation in the Western Cape. The lack of increased anthropogenic input of metals into the environment is evident in the low contamination factor values recorded for the study period, as shown in Table 6.

The mean PLI's reported here are lower than those reported by El-Sammak and Aboul-Kassim (1999), where an average of 1.28 was recorded for all of the sites they sampled. The mean PLI recorded for the five sites was 0.98 , and for the five seasons sampled was 1.00. El-Sammak and Aboul-Kassim (1999) reported that sites that had a PLI > 1.2 were considered to be affected by pollutants. Given that neither site nor season PLI values were higher than 1.2 , it is suggested that none of the sites sampled were negatively affected by exposure to metals and can thus not be considered contaminated based on PLI values.

\section{CONCLUSION}

The results of the present study provide information about the concentrations of metals in surface seawater and sediment along the western coastline of the Cape Peninsula, Cape Town. Metal concentrations at the sites sampled have not increased over the past 30 years when compared to the findings of Hennig (1985). Furthermore, the metal concentrations sampled were lower than those for other industrialised coastal cities (Acton, 2011), suggesting that Cape Town intertidal waters and sediments were not contaminated by metals. The CF and PLI analyses suggested that Scarborough was least influenced by metals whereas Bloubergstrand was most influenced by metals, in particular as a result of $\mathrm{Zn}$ levels in the sediment. Seasonally, PLI was lowest during Autumn 2010 and highest during Autumn 2011. Information from the present study can be used as baseline data, together with that reported by Hennig (1985), for future monitoring of metal concentrations in Cape Town, South Africa.

\begin{tabular}{|c|c|c|c|c|c|c|c|}
\hline \multicolumn{8}{|c|}{$\begin{array}{l}\text { TABLE } 3 \\
\text { Temporal (seasonal) and spatial Pearson's product moment correlations between metal concentrations in the surface } \\
\text { sediment }(\mu \mathrm{g} \cdot \mathrm{g}-1 \mathrm{dry} \text { weight) and water }(\mathrm{mg} \cdot \mathrm{L}-1) \text { sampled from the Cape Peninsula between Autumn } 2010 \text { and Autumn } 2011 . \\
\text { Significant correlations }(\mathrm{p}<0.05) \text { are highlighted in bold. }\end{array}$} \\
\hline \multirow{2}{*}{\multicolumn{2}{|c|}{$\begin{array}{l}\text { Metals in seawater vs surface sediment correlations } \\
\text { (for all data combined) }\end{array}$}} & $\mathrm{Fe}$ & $\mathrm{Mn}$ & $\mathrm{Cu}$ & $\mathrm{Zn}$ & $\mathrm{Cd}$ & $\mathrm{Pb}$ \\
\hline & & -0.1005 & -0.1193 & -0.0538 & 0.0018 & 0.0042 & -0.0185 \\
\hline \multirow{5}{*}{ Season } & Autumn 2010 & 0.2079 & -0.0577 & 0.1922 & 0.0315 & 0.9821 & -0.0207 \\
\hline & Winter 2010 & -0.2455 & -0.2271 & -0.0450 & -0.1280 & -0.1619 & -0.1142 \\
\hline & Spring 2010 & -0.0778 & 0.0795 & -0.0641 & -0.0422 & -0.0441 & -0.1346 \\
\hline & Summer 2010 & -0.0711 & 0.1757 & -0.1067 & 0.4869 & -0.1057 & 0.3847 \\
\hline & Autumn 2011 & 0.1427 & 0.0962 & -0.0074 & 0.3738 & 0.4290 & -0.1624 \\
\hline \multirow{5}{*}{ Site } & Scarborough & -0.0155 & -0.0195 & 0.0220 & -0.0533 & -0.1002 & -0.3888 \\
\hline & Hout Bay & 0.3920 & 0.3363 & -0.1186 & 0.0971 & 0.1514 & 0.4167 \\
\hline & Green Point & 0.4289 & 0.2014 & -0.1284 & -0.0800 & 0.8618 & -0.2353 \\
\hline & Milnerton & -0.0060 & -0.2007 & -0.0909 & 0.1313 & 0.0209 & -0.0239 \\
\hline & Bloubergstrand & -0.3525 & 0.1954 & 0.4377 & -0.0272 & 0.5209 & 0.0864 \\
\hline
\end{tabular}

\begin{tabular}{|l|c|c|c|c|c|c|c|}
\hline \multicolumn{8}{|c|}{ TABLE 4 } \\
Background metal concentrations $\left(\boldsymbol{\mu g} \cdot \mathbf{g}^{-1}\right)$ \\
Data in purface sediment for the different sites as provided by Hennig (1985). \\
\hline \multicolumn{1}{|c|}{ Site } & Year & Mn & Fe & $\mathbf{C u}$ & $\mathbf{Z n}$ & $\mathbf{C d}$ & $\mathbf{P b}$ \\
\hline Scarborough & 1985 & $(4.24)$ & $(122)$ & 4.77 & 13.5 & 3.77 & 0.86 \\
\hline Hout Bay & 1977 & 8.0 & 510 & 0.4 & 2.8 & 0.18 & 1.5 \\
\hline Green Point & 1980 & 21.5 & 1904 & 4.5 & 11.8 & 0.1 & 9.3 \\
\hline Milnerton & 1980 & 8.0 & 519 & 10 & 10 & $(1.83)$ & 1.3 \\
\hline Bloubergstrand & 1981 & 12.0 & 268 & 0.3 & 0.41 & 0.05 & 0.4 \\
\hline
\end{tabular}




\begin{tabular}{|c|c|c|c|c|c|c|c|}
\hline \multicolumn{8}{|c|}{ 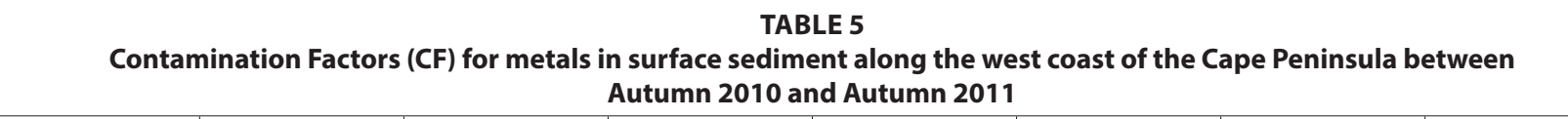 } \\
\hline Site & Mn & $\mathrm{Fe}$ & $\mathrm{Cu}$ & Zn & Cd & $\mathbf{P b}$ & Mean \\
\hline \multicolumn{8}{|c|}{ Autumn 2010} \\
\hline Scarborough & $<0.01$ & $<0.01$ & $<0.01$ & $<0.01$ & $<0.01$ & $<0.01$ & $<0.01$ \\
\hline Hout Bay & 1.28 & 1.40 & 1.78 & 6.15 & 0.57 & 2.52 & 2.28 \\
\hline Green Point & 0.40 & 0.01 & 0.16 & 0.07 & 19.63 & 0.22 & 3.42 \\
\hline Milnerton & 0.81 & 0.85 & 0.04 & 0.23 & 0.03 & 1.34 & 0.55 \\
\hline Bloubergstrand & 0.94 & 2.84 & 5.04 & 16.71 & 0.92 & 3.65 & 5.02 \\
\hline Mean & 0.69 & 1.02 & 1.40 & 4.63 & 4.23 & 1.55 & 2.25 \\
\hline \multicolumn{8}{|c|}{ Winter 2010} \\
\hline Scarborough & 0.37 & 0.22 & $<0.01$ & $<0.01$ & $<0.01$ & 0.20 & 0.13 \\
\hline Hout Bay & 1.24 & 1.44 & $<0.01$ & $<0.01$ & 0.55 & 0.72 & 0.66 \\
\hline Green Point & 0.99 & 1.35 & $<0.01$ & 0.21 & 0.39 & 0.48 & 0.57 \\
\hline Milnerton & 0.69 & 1.04 & 0.10 & 1.12 & 0.04 & 1.71 & 0.79 \\
\hline Bloubergstrand & 0.12 & 0.60 & $<0.01$ & 484.65 & 91.53 & 3.63 & 96.76 \\
\hline Mean & 0.68 & 0.93 & 0.02 & 97.20 & 18.51 & 1.35 & 19.78 \\
\hline \multicolumn{8}{|c|}{ Spring 2010} \\
\hline Scarborough & 1.06 & 0.61 & 0.70 & $<0.01$ & 0.01 & 0.41 & 0.46 \\
\hline Hout Bay & 1.13 & 1.10 & 44.10 & 0.81 & 0.38 & 0.51 & 8.01 \\
\hline Green Point & 0.76 & 0.79 & 1.19 & 2.20 & 3.12 & 0.44 & 1.41 \\
\hline Milnerton & 0.68 & 0.81 & 0.25 & 0.09 & 0.08 & 1.66 & 0.58 \\
\hline Bloubergstrand & 0.63 & 1.69 & 0.80 & 0.19 & 0.35 & 2.70 & 1.06 \\
\hline Mean & 0.85 & 1.00 & 9.41 & 0.66 & 0.78 & 1.14 & 2.31 \\
\hline \multicolumn{8}{|c|}{ Summer 2010} \\
\hline Scarborough & 0.55 & 0.71 & 0.03 & 0.03 & 0.01 & 0.38 & 0.28 \\
\hline Hout Bay & 0.91 & 1.46 & 0.55 & 0.14 & 0.03 & 0.41 & 0.59 \\
\hline Green Point & 1.24 & 2.28 & 1.28 & 0.55 & 0.13 & 0.65 & 1.02 \\
\hline Milnerton & 0.69 & 1.03 & 0.04 & 1.71 & 0.02 & 1.41 & 0.82 \\
\hline Bloubergstrand & 0.94 & 2.40 & 1.88 & 70.14 & $<0.01$ & 3.14 & 13.08 \\
\hline Mean & 0.87 & 1.58 & 0.76 & 14.51 & 0.04 & 1.20 & 3.16 \\
\hline \multicolumn{8}{|c|}{ Autumn 2011} \\
\hline Scarborough & 1.15 & 0.60 & 0.21 & $<0.01$ & 0.02 & 0.71 & 0.45 \\
\hline Hout Bay & 1.53 & 1.71 & 8.06 & 0.13 & 0.85 & 0.88 & 2.19 \\
\hline Green Point & 1.15 & 1.58 & 0.94 & 1.06 & 0.50 & 0.51 & 0.96 \\
\hline Milnerton & 1.17 & 1.39 & 0.34 & 0.19 & 0.09 & 2.31 & 0.91 \\
\hline Bloubergstrand & 0.43 & 1.23 & 3.45 & 17.78 & 0.83 & 1.76 & 4.25 \\
\hline Mean & 1.09 & 1.30 & 2.60 & 3.83 & 0.46 & 1.23 & 1.75 \\
\hline
\end{tabular}

\section{TABLE 6}

Pollution Load Index (PLI) for metals in surface sediment along the west coast of the Cape Peninsula between Autumn 2010 and Autumn 2011

\begin{tabular}{|l|c|c|c|c|c|c|}
\hline \multicolumn{1}{|c|}{ Site } & Autumn 2010 & Winter 2010 & Spring 2010 & Summer 2010 & Autumn 2011 & Average \\
\hline Scarborough & 0.4385 & 0.8688 & 0.8889 & 0.8918 & 0.9046 \\
\hline Hout Bay & 1.0240 & 0.9946 & 1.0379 & 0.9502 & 1.0439 \\
\hline Green Point & 0.9122 & 0.9789 & 0.9995 & 0.9862 & 0.9871 \\
\hline Milnerton & 0.8979 & 0.9558 & 0.9196 & 0.9504 & 0.9668 \\
\hline Bloubergstrand & 1.0613 & 1.0507 & 0.9967 & 1.1127 & 0.9635 \\
\hline Average & 0.8668 & 0.9697 & 0.9685 & 0.9782 & 1.0156 \\
\hline
\end{tabular}




\section{ACKNOWLEDGEMENTS}

The authors would like to thank the Cape Peninsula University of Technology (University Research Funding) for funding this project. We would also like to express sincere thanks to the Departmental Technician, Michelle Slabber, for technical support during field surveys and laboratory work.

\section{REFERENCES}

ABDALLAH MAM and ABDALLAH AMA (2008) Biomonitoring study of metals in biota and surface sediments in the South Eastern coast of Mediterranean sea, Egypt. Environ. Monit. Assoc. 146 139-145. https://doi.org/10.1007/s10661-007-0066-8

ACTON QA (2011) Issues in Global Environment: Freshwater and Marine Environments. Scholarly Editions, Atlanta.

ANKLEY GT, DI TORO M, HANSEN DJ and BERRY WJ (1996) Technical basis and proposal for deriving surface sediment quality criteria from metals. Environ. Toxicol. Chem. 15 2056-2066. https:// doi.org/10.1002/etc.5620151202

CLARK RB, FRID C and ATTRILL M (1992) Marine Pollution. Clarendon Press, Oxford.

CLARKE KR and GORLEY RN (2006) PRIMER v6: User Manual/ Tutorial. PRIMER-E Ltd, Plymouth.

DUFFUS JH (1980) Environmental Toxicology. Edwards Arnold Publishers, London.

EL-SAMMAK AA and ABOUL-KASSIM TA (1999) Metal pollution in the surface sediments of Alexandria Region, Southeastern Mediterranean, Egypt. Bull. Environ. Contam. Toxicol. 63 263-270. https://doi.org/10.1007/s001289900975

GIARRATANO E, DUARTE CA and AMIN OA (2010) Biomarkers and metal bioaccumulation in mussels transplanted to coastal waters of the Beagle Channel. Ecotoxic. Environ. Saf. 73 270-279. https://doi. org/10.1016/j.ecoenv.2009.10.009

GLASS G (1981) Geology, morphology, surface sediment cover and movement. In: Gasson B (ed) The Future Management of False Bay. False Bay Conservation Society, University of Cape Town, Cape Town.

GOLDBERG ED, KOIDE M, HODGE V, FELGAL A and MARTIN (1983) U.S. Mussel Watch: 1977-1978 results on trace metals and radionuclides. Estuar. Coast. Shelf Sci. 16 69-93. https://doi. org/10.1016/0272-7714(83)90095-1

HENNIG HF-KO (1985) Review of metal concentrations in Southern African coastal waters, surface sediments and organisms. South African National Scientific Programme unpublished report no. 108

HUTZINGER O (1980) The Handbook of Environmental Chemistry. Volume 1, Part A. Springer Verlag, Berlin.

KENNISH MJ (1997) Practical Handbook of Estuarine and Marine Pollution. CRC Press Marine Science Series, Florida, USA

MUBIANA VK, QADAH D, MEYS J and BLUST R (2005) Tempora and spatial trends in heavy metal concentrations in the marine mussel Mytilus edulis from the Western Scheldt estuary (The Netherlands). Hydrobiologia 540 169-180. https://doi.org/10.1007/ s10750-004-7134-7
MUSTARD PJ and COWLING RM (1993) The role of regeneration stages in the distribution of edaphically restricted Fynbos Proteaceae. Ecol. Soc. Am. 74 1490-1499.

NAHMAN A and GODFREY L (2010) Economic instruments for solid waste management in South Africa: Opportunities and constraints. Resour. Conserv. Recycl. 54 521-531. https://doi.org/10.1016/j. resconrec.2009.10.009

ODENDAAL JP and REINECKE AJ (1999) The sublethal effects and accumulation of cadmium in the terrestrial isopod Porcellio laevis Latr. (Crustacea, Isopoda). Arch. Environ. Contam. Toxicol. 36 64-69. https://doi.org/10.1007/s002449900443

PRZYTARSKA JE, SOKOŁOWSKI A, WOŁOWICZ M, HUMMEL H and JANSEN J (2010) Comparison of trace metal bioavailabilities in European coastal waters using mussels from Mytilus edulis complex as biomonitors. Environ. Monit. Assess. 166 461-476. https://doi. org/10.1007/s10661-009-1015-5

QUICK AJR and ROBERTS MJ (1992) Table Bay: Synthesis of available information and management recommendations. City of Cape Town Municipality, Cape Town.

REBELO AG, HOLMES PM, DORSE C and WOOD J (2011) Impacts of urbanization in a biodiversity hotspot: Conservation challenges in metropolitan Cape Town. S. Afr. J. Bot. 77 20-35. https://doi. org/10.1016/j.sajb.2010.04.006

RILEY JP and CHESTER R (1983) Chemical Oceanography. Volume 8. Academic Press, London.

RILEY JP and SKIRROW G (1975) Chemical Oceanography. Volume 4. Academic Press, London.

SALOMONS W and FÖRSTNER U (1984) Metals in the Hydrocycle. Springer Verlag, Berlin. https://doi.org/10.1007/978-3-642-69325-0

SARKI MK, CASTERBERRY DT, MAY T, MARTIN BA and BULLARD FN (1995) Copper, cadmium and zinc concentrations in aquatic food chains from the Upper Sacramento River (California) and tributaries. Arch. Environ. Contam. Toxicol. 24 484-491.

SHANNON L (1985) The Benguela ecosystem part I. Evolution of the Benguela, physical features and processes. Ocean. Mar. Biol. Ann. Rev. 23 105-182.

SHUPING LS (2008) Biomonitoring of metal contamination in the lower Diep River, Milnerton, Western Cape. MTech thesis, Cape Peninsula University of Technology, South Africa.

TALJAARD S (2006) Baseline assessment of sources and management of land based marine pollution in the BCLME Region. Project BEHP/ LBMP/03/01. CSIR, Stellenbosch.

ÜNLÜ S, TOPÇUOĞLU S, ALPAR B, KIRBAŞOĞLU C and YILMAZ Y (2008) Metal pollution in surface sediment and mussel samples in the Gulf of Gemlik. Environ. Monit. Assess. 144 169-178. https://doi org/10.1007/s10661-007-9986-6

VAN IEPEREN MP (1971) Hydrology of Table Bay. Final report. Institute of Oceanography. University of Cape Town, South Africa.

WHO (World Health Organization) (1982) Waste Discharge into the Marine Environment. Principles and Guidelines for the Mediterranean Action Plan. United Nations Environment Programme. Pergamon Press, Oxford.

WHO (World Health Organization) (1992) Cadmium. Environmental Health Criteria Series 61. WHO, Geneva.

WRIGHT DA AND WELBOURN P (2002) Environmental Toxicology. Cambridge University Press, Cambridge. 